\title{
Medication and nutritional supplement use before and after bariatric surgery
}

\author{
Utilização de medicamentos e suplementos nutricionais antes e após a \\ cirurgia bariátrica
}

\author{
Charline Fernanda Backes', Edyane Lopes", Airton Tetelbom"', Isabela Heineck ${ }^{\text {IV }}$ \\ School of Pharmacy, Universidade Federal do Rio Grande do Sul (UFRGS), Porto Alegre, RS, Brazil
}

'Master's Student in the Postgraduate Pharmaceutical Sciences Program, Universidade Federal do Rio Grande do Sul (UFRGS), Porto Alegre, RS, Brazil.

"PhD. Pharmacist, School of Public Health, Health Department of the State of Rio Grande do Sul, Porto Alegre, RS, Brazil.

"'MD. Coordinator of the Health Technology Assessment Center, Grupo Hospitalar Conceição; Head Professor of Public Health, Universidade Federal de Ciências da Saúde de Porto Alegre (UFCSPA); Associate Professor of Public Health, Universidade Luterana do Brasil (ULBRA); and Contributing Professor in the Postgraduate Epidemiology Program, Department of Social Medicine, School of Medicine, Universidade Federal do Rio Grande do Sul (UFRGS), Porto Alegre, RS, Brazil. vphD. Associate Professor, Postgraduate Pharmaceutical Sciences Program and Postgraduate Pharmaceutical Services, School of Pharmacy, Universidade Federal do Rio Grande do Sul (UFRGS), Porto Alegre, RS, Brazil.

\section{KEY WORDS:}

Bariatric surgery.

Comorbidity.

Pharmaceutical preparations.

Gastric bypass.

Obesity, morbid.

\section{PALAVRAS-CHAVE: \\ Cirurgia bariátrica. \\ Comorbidade. \\ Preparações farmacêuticas. \\ Derivação gástrica. \\ Obesidade mórbida.}

\begin{abstract}
CONTEXT AND OBJECTIVE: Bariatric surgery has been an effective alternative treatment for morbid obesity and has resulted in decreased mortality, better control over comorbidities and reduced use of drugs. The objective of this study was to analyze the impact of bariatric surgery on medication drug and nutritional supplement use.
\end{abstract}

DESIGN AND SETTING: Longitudinal study of before-and-after type, on 69 morbidly obese patients in a public hospital in Porto Alegre.

METHODS: Through interviews, the presence of comorbidities and use of drugs with and without prescription were evaluated.

RESULTS: Among the 69 patients interviewed, $85.5 \%$ had comorbidities in the preoperative period, with an average of 2.3 ( \pm 1.5) per patient. The main comorbidities reported were hypertension, diabetes and dyslipidemia. $84.1 \%$ of the patients were using prescribed drugs in the preoperative period. The mean drug use per patient was 4.8 , which decreased to 4.4 after the procedure. The surgery enabled significant reduction in use of most antidiabetic (84\%), antilipemic (77\%) and antihypertensive drugs (49.5\%). On the other hand, there was a significant increase in use of multivitamins and drugs for disorders of the gastrointestinal tract. The dosages of most of the drugs that continued to be prescribed after surgery were decreased, but not significantly.

CONCLUSION: After bariatric surgery, there were increases in the use of vitamins, gastric antisecretory drugs and antianemic drugs. Nevertheless, there was an overall reduction in drug use during this period, caused by suspension of drugs or dose reduction.

\section{RESUMO}

CONTEXTO E OBJETIVO: A cirurgia bariátrica tem sido uma alternativa efetiva de tratamento para a obesidade mórbida, resultando na diminuição da mortalidade, melhor controle das comorbidades e redução no uso de medicamentos. O objetivo deste estudo foi analisar o impacto da cirurgia bariátrica sobre a utilização de medicamentos e suplementos nutricionais.

TIPO DE ESTUDO E LOCAL: Estudo longitudinal do tipo antes e depois com 69 pacientes obesos mórbidos em um hospital público de Porto Alegre.

MÉTODOS: Nas entrevistas, foram avaliados a presença de comorbidades e o uso de medicamentos com e sem prescrição médica.

RESULTADOS: De 69 pacientes entrevistados, 85,5\% apresentaram comorbidades no período pré-cirúrgico, média de 2,3 $( \pm 1,5)$ por paciente. As principais comorbidades relatadas foram hipertensão, diabetes e dislipidemias. $84,1 \%$ dos pacientes estavam em uso de medicamentos sob prescrição médica, no período pré-cirúrgico. A média de uso de medicamentos por paciente foi de 4,8, reduzindo para 4,4 após o procedimento. A cirurgia proporcionou diminuição significativa do uso da maioria dos antidiabéticos (84\%), antilipêmicos (77\%) e anti-hipertensivos (49,5\%). Por outro lado, observou-se aumento significativo na utilização de multivitamínicos e medicamentos para desordens do trato gastrointestinal. A maior parte dos medicamentos que continuaram sendo prescritos após a cirurgia teve sua dose reduzida, no entanto, esta redução não foi significativa.

CONCLUSÃO: Após a cirurgia bariátrica, observou-se aumento na utilização de vitaminas, antisecretores gástricos e antianêmicos. No entanto, de forma geral, houve redução na utilização de medicamentos neste período, ocasionada pela suspensão de medicamentos ou redução de doses. 


\section{INTRODUCTION}

Chronic non-communicable diseases are one of the biggest public health issues today. ${ }^{1}$ Obesity stands out in this regard and has been officially acknowledged by the World Health Organization (WHO) as a chronic disease. ${ }^{2}$

The number of obese individuals has been increasing worldwide and has reached an average of $30 \%$ of the adult population in some countries. ${ }^{3}$ In Brazil, poor dietary habits have been reflected in the population's health and in increasing prevalence of overweight. More than half of all Brazilians (51\%) are now overweight, and $17 \%$ of these individuals are obese. ${ }^{1}$

Fighting this rapid growth is one of the biggest challenges for world health, given that obesity is frequently associated with a vast array of comorbidities, such as systemic arterial hypertension, type 2 diabetes mellitus, dyslipidemia, obstructive sleep apnea, cardiovascular diseases and some types of cancer. ${ }^{4-8}$ Most patients with high blood pressure are overweight, ${ }^{9}$ and hypertension is six times more frequent among obese individuals than among those with normal weight. ${ }^{10}$

The alternatives to clinic treatment for reducing weight among patients with morbid obesity are limited, and the longterm outcomes are relatively inefficient. ${ }^{11}$ Bariatric surgery seems to be a viable option for treating morbid obesity, since it has been shown to be effective in maintaining the weight loss. A significant improvement in comorbidities and even their regression may be observed in most patients who undergo this surgical procedure for weight loss. ${ }^{10}$ This surgical procedure has been shown to enable control over glucose levels, even leading to remission of diabetes. ${ }^{12}$ The quick and sustained improvement in glucose homeostasis that this procedure provides has made it the gold-standard metabolic procedure and treatment for diabetic patients with morbid obesity. ${ }^{13}$ Comorbidity reductions are reflected in diminished drug use during the postoperative period, and discontinuation of drug therapy for some diseases, thus resulting in reduced expenditure on drugs and other healthcare services. ${ }^{10,14-18}$

In addition, bariatric surgery extends survival, decreases occurrences of cardiovascular events and is also associated with greater reduction of mortality due to cardiovascular diseases, myocardial infarction, stroke, diabetes and cancer, in comparison with obese individuals who do not undergo this surgery. ${ }^{10,19,20}$ The reduction in the risk of myocardial infarction, stroke and adverse cardiovascular events is approximately 50\% after this surgery, in comparison with individuals who did not undergo the procedure. ${ }^{19}$

If, on the one hand, bariatric surgery reduces the need for medication to treat comorbidities; on the other hand, the restrictive and disabsorptive procedures involved pose a higher risk of deficiencies of vitamins and minerals. ${ }^{21}$ However, studies assessing drug use and their respective dosages after bariatric surgery are still scarce.

\section{OBJECTIVE}

Within this context, this study aimed to assess the impact of bariatric surgery on medication drug use among morbidly obese patients, before and after the procedure, focusing mainly on the number of drugs used, drug classes and posology.

\section{METHODS}

This was a longitudinal study of before-and-after type, carried out between 2008 and 2011 in the endocrinology clinic of the service for assisting morbidly obese individuals at Hospital Nossa Senhora da Conceição (HNSC) in the city of Porto Alegre, which works under the National Health System (Sistema Único de Saúde, SUS). Through this service, four to five operations per month are performed on patients coming from several regions of the state of Rio Grande do Sul. The clinic offers care provided by physicians (endocrinologist, surgeon and psychiatrist), psychologists, nutritionists and nurses.

The patients eligible for surgical treatment are those with BMI greater than $40 \mathrm{~kg} / \mathrm{m}^{2}$ or greater than $35 \mathrm{~kg} / \mathrm{m}^{2}$ in association with comorbidities, after failure in applying traditional measures for weight loss. They need to be psychologically capable of following dietary orientation during the postoperative period, as well as presenting absence of endocrine causes of obesity. ${ }^{22-24}$

The sample size was estimated to be 52 patients, taking into consideration the reduction in drug use for treating hypertension and cardiovascular disease (HT/CVD) that has been reported in the literature. ${ }^{25}$ The reduction in drug use expected after the intervention was $49 \%$. Considering the probability that some patients would be lost from the follow-up, it was decided to increase the sample size by $30 \%$. Thus, after the research project had been approved by the HNSC Research Ethics Committee (report no. 146/08), and after potential participants had signed an informed consent statement authorizing data use, 69 individuals with morbid obesity (convenience sampling), who were waiting for biliopancreatic diversion with duodenal switching (BPD-DS) and Roux-en-Y gastric bypass (RYGBP), were interviewed.

Individuals aged over 18 years with class III obesity (body mass index, BMI, greater than $40 \mathrm{~kg} / \mathrm{m}^{2}$ ) and those with BMI greater than $35 \mathrm{~kg} / \mathrm{m}^{2}$ in association with comorbidities, who were willing to participate in the study, had presented stable obesity for at least five years and had had at least two years of previous inefficient clinical treatment, were included in this study. Patients who did not adhere to preoperative monitoring appointments, had comprehension difficulties (which made them unable to make decisions) or had already undergone another surgical 
procedure with the aim of losing weight (gastric sleeve) were excluded from the study.

Data were gathered through 40-minute interviews that were conducted with all patients one day before the procedure and again six months after it. A structured questionnaire was used to assess the variables of gender, age, weight, drug use, reasons for undergoing the surgery and comorbidities. To confirm the presence of comorbidities, drug use, weight and height, some data from the patients' records were used.

Information on drug use at the time of the interviews was initially gathered through the open question "What medications do you take?" For each drug, the name, daily dose, indication and whether its use was through self-medication or prescription were registered. To minimize data loss through forgetfulness, the participants were also asked about their drug use by specifying organs or systems (for example: "Do you take any drug for heart disease?").

The proportion of patients using each drug was calculated taking into consideration the total number of patients using the drug at each time: preoperatively, $\mathrm{n}=69$; postoperatively, $\mathrm{n}=64$. To evaluate dose variability, the sum of the doses of each drug divided by the number of patients using this drug at each time was calculated.

The data were double-input into the Epi Data 2.1a. software. They were analyzed through the Statistical Package for the Social Sciences (SPSS) version 18.0 and the Winpepi software. Comparative and descriptive analyses were performed, expressing frequency, average, standard deviation and P-values. McNemar's chi-square test was applied to compare the numbers of patients using drugs before and after the procedure. Student's $t$ test was applied to analyze the dosages. P values $\leq 0.05$ were considered significant.

\section{RESULTS}

During the preoperative period, 69 patients who were scheduled to undergo bariatric surgery were monitored. There were no refusals to participate. However, after the procedure, there was a loss of five cases: four patients did not return to the consultations in the hospital and one patient died. The majority of the patients participating in this study were women $(91.3 \%)$ and married (46.5\%). Their mean age was 42.3 ( \pm 10.4 ); they had a mean of 9 $( \pm 2.3)$ years of education and had undergone a mean of $4( \pm 1.3)$ years of preoperative monitoring. Their mean BMI before the operation was $51.07( \pm 7.8) \mathrm{kg} / \mathrm{m}^{2}$, and after the operation it was $35.9( \pm 7.2) \mathrm{kg} / \mathrm{m}^{2}$ (Table 1 ).

During the preoperative period, $85.5 \%$ of the patients presented one to five comorbidities associated with obesity, with a mean of 2.33 ( \pm 1.47) per patient. The patients between 20 and 25 years of age did not present any comorbidities. On the other hand, comorbidities were present in all patients aged over 49 years. Hypertension, diabetes, high cholesterol level, hypothyroidism, arthrosis/arthritis, asthma, depression and circulatory problems were the main issues reported prior to surgery. After the procedure, significant reductions in hypertension and diabetes were observed. Dyslipidemia, hypothyroidism, arthrosis/arthritis and depression presented reductions, but not significantly (Table 2).

The surgical technique most often used was gastric bypass (91.4\%). The subjects mentioned the following as the main reasons for undergoing the surgery: desire to have better health $(42.9 \%)$, desire for better quality of life $(11.1 \%)$, desire for weight loss $(11.1 \%)$, tiredness $(6.3 \%)$, difficulty in moving around $(6.3 \%)$, sore legs $(4.8 \%)$, backache $(3.2 \%)$ and prejudice $(3.2 \%)$.

Among the 69 patients interviewed before the surgery, $84.1 \%$ reported using drugs through medical prescription, whereas $73.9 \%$ did this through self-medication. At the time of the postoperative assessment, $82.6 \%$ and $50.7 \%$ took drugs, respectively with and without prescription. Use of 328 drugs was observed before the operation, with an average of 4.8 drugs per patient,

Table 1. Characteristics of patients undergoing bariatric surgery at Hospital Nossa Senhora da Conceição between 2008 and 2011 ( $n=69$ )

\begin{tabular}{lcc|}
$\begin{array}{l}\text { Baseline characteristics } \\
\text { Mean age (years) }\end{array}$ & Mean (SD), \% (n) \\
$\begin{array}{l}\text { School education (years) } \\
\text { Preoperative monitoring (years) }\end{array}$ & $42.3(10.4)$ \\
Marital status & Married & $9(2.3)$ \\
& Single & $4(1.3)$ \\
Gender & Female & $62.3 \%(43)$ \\
& Male & $37.7 \%(26)$ \\
BMI & Preoperative & $91.3 \%(63)$ \\
& Postoperative & $8.7 \%(6)$ \\
\hline
\end{tabular}

$\mathrm{SD}=$ standard deviation; $\mathrm{BMI}=$ body mass index .

Table 2. Main comorbidities shown at pre and postoperative assessments

\begin{tabular}{lcc|} 
Comorbidities & $\begin{array}{c}\text { Preoperative number } \\
\text { of patients with } \\
\text { comorbidities } \\
\mathbf{n = 6 9}\end{array}$ & $\begin{array}{c}\text { Postoperative number } \\
\text { of patients with } \\
\text { comorbidities }\end{array}$ \\
\hline Hypertension & $45(65.2 \%)$ & $\mathbf{n = 6 4}$ \\
Diabetes & $20(28.9 \%)$ & $19(29.7 \%)^{*}$ \\
Dyslipidemias & $11(15.9 \%)$ & $4(6.3 \%)^{*}$ \\
Hypothyroidism & $9(13 \%)$ & $4(6.3 \%)$ \\
\hline Arthrosis/arthritis & $9(13 \%)$ & $6(9.4 \%)$ \\
\hline Depression & $8(11.6 \%)$ & $4(6.3 \%)$ \\
\hline
\end{tabular}

${ }^{*} \mathrm{P} \leq 0.05$ (chi-square test). 
whereas after the operation this use reduced to 284 drugs, with an average of 4.4 per patient.

A significant reduction in the use of antihypertensive drugs (49.5\%) was observed, except for propranolol. Decreases in the use of antidiabetic (84\%), antidepressant (30\%), antilipemic (50\%), muscle relaxant (33.3\%), painkiller (35.3\%) and anti-inflammatory $(78.5 \%)$ drugs were also observed, and these decreases were significant for the following drugs: metformin, fluoxetine, simvastatin, acetylsalicylic acid (ASA), diclofenac and paracetamol. On the other hand, there were significant increases in the use of vitamin supplements and drugs relating to disorders of gastrointestinal tract, such as omeprazole (Table 3 ).

Moreover, reductions in daily dosages were observed for antidiabetic, antilipemic, antidepressant, antithrombotic and most antihypertensive drugs. The differences observed in relation to the dosages were not significant.

\section{DISCUSSION}

Our results showed that use of antidiabetic, antihypertensive, painkiller, antilipemic and antidepressant drugs had decreased by the time of the assessment six months after surgery. However, increases in the numbers of drugs used to treat gastrointestinal disorders, anemia and vitamin deficiency were observed.

Among the patients who kept on using drugs after the surgery, reductions in dosages were observed in most of the cases, mainly in relation to antihypertensive drugs (except for hydrochlorothiazide), antidiabetic drugs and antidepressants; however, these reductions were not significant.

Table 3. Differences observed in relation to the main therapeutic classes, drugs and mean daily dosages used before and after bariatric surgery

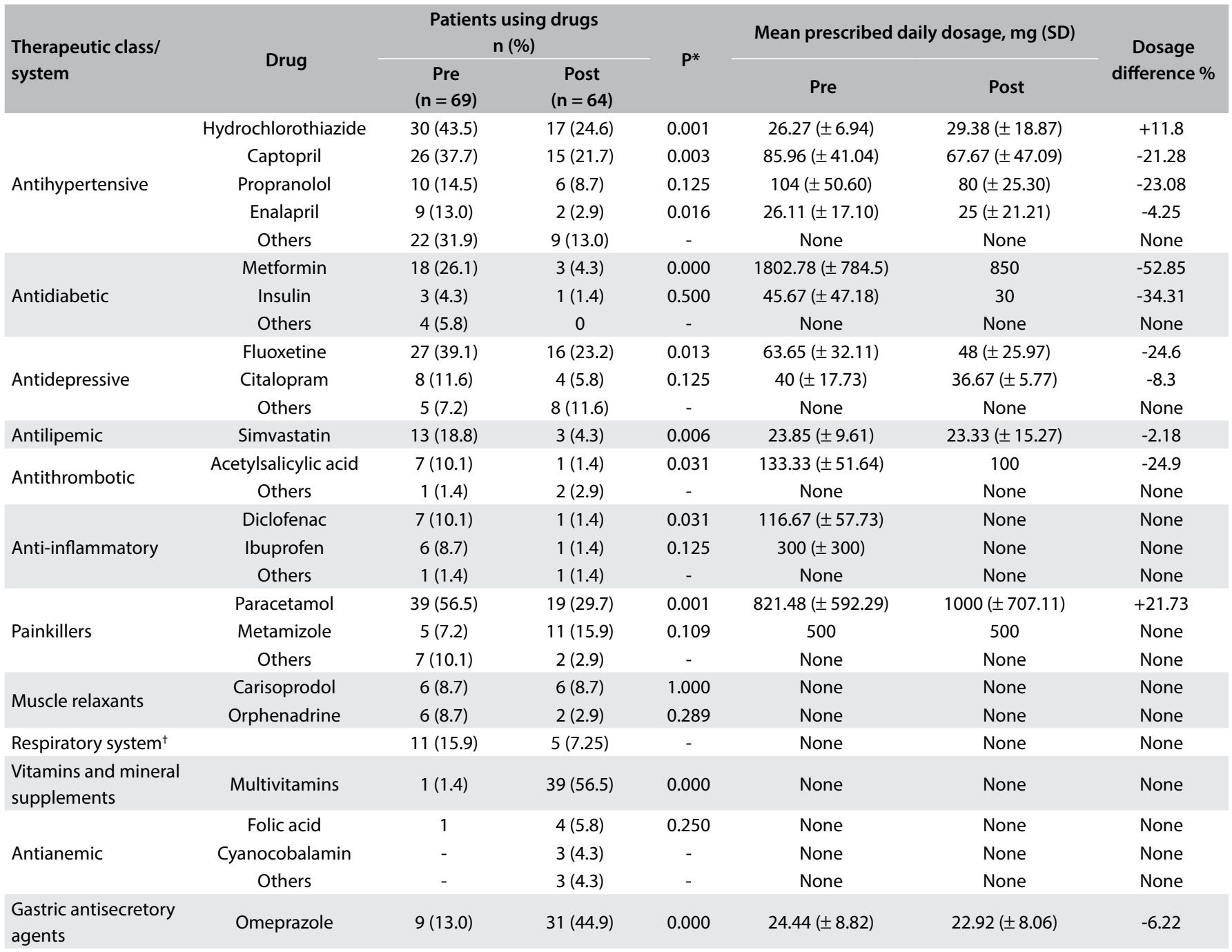

SD = standard deviation; ${ }^{*}$ McNemar's chi-square test; ${ }^{\dagger}$ oxymetazoline (1 patient), xylometazoline (1), salbutamol (2), fenoterol (1), salmeterol and fluticasone (1), formoterol and budesonide (2), beclometasone (1), dexchlorpheniramine (1) and loratadine (1). 


\section{Antidiabetic drugs}

The number of patients using antidiabetic drugs decreased by $84 \%$ during the postoperative period. Reductions in mean daily dosages of antidiabetic drugs were also observed. Our results are consistent with those of other authors. Maciejewski et al. ${ }^{26}$ reported that there was a $50 \%$ reduction in the use of antidiabetic drugs within one year after bariatric surgery. Additionally, Potteiger et al. ${ }^{27}$ and Narbro et al. ${ }^{28}$ reported that there were significant reductions in the numbers and cost of drugs used to treat diabetes relating to obesity, after surgery. Importantly, the features of the population and the follow-up period need to be taken into account in assessing these proportions, because the impact of surgery on antidiabetic drug use may vary according to these factors. ${ }^{29}$

The great majority of the patients with type 2 diabetes experience more favorable results from clinical examinations, after undergoing bariatric surgery. The mortality rate associated with diabetes has also been significantly reduced. ${ }^{10}$ A more recent study that assessed the long-term effects of bariatric surgery on diabetic patients observed that glucose control and remission from diabetes were possible in $89.2 \%$ and $64.7 \%$ of the patients, respectively. ${ }^{30}$ Similar findings had already been reported previously. ${ }^{31}$

Furthermore, reduction of diabetes has been found to occur more frequently among patients who underwent gastric bypass surgery that excluded the duodenum from the nutrient pathway and changed the bowel metabolism, thus reducing insulin resistance faster. ${ }^{32}$ Therefore, the significant decrease in antidiabetic drug use observed in our study might be related to the surgical technique used on most subjects (91\%).

Recent studies have also suggested that the remission mechanism of this comorbidity in the postoperative period may be categorized into two groups: unconnected with weight loss and connected with it. Although weight loss is an aspect common to all techniques, gastric bypass has shown improvement in diabetes over the short term, regardless of weight loss. ${ }^{33,34}$ The underlying mechanisms for this are still being studied..$^{35-42}$

Metformin, the most widely used antidiabetic drug, is absorbed slowly and incompletely by the gastrointestinal tract, mainly from the small intestine onwards. Studies suggest that this drug reaches saturation of absorption, since its concentration in the plasma does not increase with administration of everhigher dosages. ${ }^{43}$

Metformin dosage has to be carefully individualized, based on patients' tolerance and response. Side effects, especially gastrointestinal effects, are observed in approximately 5 to $50 \%$ of the patients and seem to be related to dosage. ${ }^{43}$

Regarding pharmacokinetics, few studies have focused on antidiabetic drug absorption after bariatric surgery. However, Aron-Wisnevsky ${ }^{44}$ observed that metformin bioavailability seems to increase after gastric bypass, thus increasing the risk of toxicity. Therefore, the decrease in dosage observed in our study might be partly related to these findings.

\section{Antihypertensive drugs}

A reduction in the number of patients using antihypertensive drugs during the postoperative period was observed (49.5\%) The mean daily dosages became smaller for most drugs, except for hydrochlorothiazide. Increases in dosage may be due to exclusion of other antihypertensive drugs. According to the BAROS system (Bariatric Analysis and Reporting Outcome System), arterial hypertension is resolved after bariatric surgery when patients continue to use diuretics alone. ${ }^{45,46}$

Regarding the reduction in the number of patients who were using antihypertensive drugs, our findings were similar to those reported by other authors. ${ }^{26-28,47,48}$ Partial or complete improvement was shown within 12 months after undergoing bariatric surgery, especially among the patients who had undergone gastric bypass, ${ }^{10,47}$ thus reducing the need for antihypertensive drugs. ${ }^{49,50}$ It seems again that our results were somehow related to the technique used for the majority of our patients, i.e. gastric bypass.

Reductions in plasma catecholamines and renin activity brought about by weight loss is associated with decreased sympathetic activity, and is likely to be a determining factor for controlling hypertension. ${ }^{51-53}$ Thus, it can be suggested that these factors may have contributed towards decreased antihypertensive drug use after loss of excessive weight due to the bariatric surgery.

\section{Antilipemic drugs}

Approximately $50 \%$ of the patients undergoing surgery for weight loss present dyslipidemia, which is a major factor relating to morbidity and mortality rates. ${ }^{16,54}$ Weight loss significantly improves patients' lipid profiles. Reductions in triglycerides, total cholesterol and low-density lipoprotein (LDL) levels, and increases in high-density lipoprotein (HDL) occur. Within less than one year, most patients who previously needed lipid-lowering drugs are able to discontinue their use. ${ }^{16}$

Our results confirm the findings from previous studies. ${ }^{16,54}$ A marked decrease in the number of patients using simvastatin was observed. These results suggest that not only was the surgery effective for weight loss, but also it was an efficient alternative for treating dyslipidemia among these severely obese individuals. Improvement in lipid profile is related to the technique used, and disabsorptive techniques cause more significant changes. However, the mechanisms involved in dyslipidemia reduction following bariatric surgery have not been clarified yet. ${ }^{10}$

Regarding the dosage of antilipemic drugs, there are some reports on atorvastatin in the literature, suggesting that its 
bioavailability increases after the surgical procedure, thus allowing reduction of the dosage. ${ }^{44}$ Nevertheless, it is not known whether the same occurs with simvastatin. In our study, for patients who continued using simvastatin after surgery, there was no clinically significant reduction in daily dosage use.

\section{Multivitamins and antianemic drugs}

Multivitamin supplementation is recommended during the postoperative period, in order to correct nutritional deficiencies, ${ }^{55,56}$ especially those relating to vitamins B12, A and D, thiamine, folate and minerals such as iron, zinc and calcium. ${ }^{57,58}$ Such deficiencies frequent occur after bariatric surgery and relate to decreased food intake and physiological changes produced by the surgery..$^{59,60}$

Gastric bypass changes how food passes along the gastrointestinal tract and leads to poor nutrient absorption, given that food is exposed to the jejunum earlier than usual, through exclusion of part of the gastric and duodenal surface. ${ }^{61}$ The absorbent surface area and solubility, and consequently drug bioavailability, are affected by this technique. ${ }^{44,57}$

Our results support previous findings in that they indicated that there was a significant increase in vitamin use that might be related to the surgical technique (91\%), as well as decreased food intake after the surgery. Furthermore, an increase in the use of antianemic drugs during the postoperative period was observed. Iron deficiency during this period was very evident. ${ }^{21}$

\section{Gastric antisecretory agents}

Unlike our study, in which a significant increase in the use of antisecretory agents was observed, Crémieux ${ }^{55}$ and Fontana and Wohlgemuth ${ }^{62}$ reported reductions in the use of these drugs for up to three years after the surgery. This decrease might be connected with the reduced occurrence of gastroesophageal reflux over time, which might remain stabilized for up to three years. The difference in the results reported by these authors, ${ }^{55}$ in comparison with our study, might be associated with the duration of the postoperative follow-up among the patients and with the standard of service rendered.

Development of stomach ulcers is one of the biggest and most common complications associated with the gastric bypass technique, ${ }^{63,64}$ and it is reported in $1 \%$ to $20 \%$ of the patients after surgery. ${ }^{65,66}$ Stomach ulcers may develop over the short term, possibly associated with technical problems at the intervention site. ${ }^{67}$ They are usually located in the damaged intestinal mucosa, unable to withstand acidity; they may also be located near the anastomosis. ${ }^{66}$ Stapling during the surgery, use of anti-inflammatory drugs or presence of Helicobacter pylori (H. pylori) during the preoperative period may provoke development of late ulcers. Previous reports in the literature suggest that $H$. pylori damages the mucosal barrier, and that this damage persists into the postoperative period. This induces exacerbation of the ulcer, even if the organism has already been treated. ${ }^{63,68,69}$ All these factors may have influenced the increased prescription of antisecretory drugs observed in this study.

\section{Antidepressants}

There are few studies relating to the effect of bariatric surgery on the use of drugs that act on the central nervous system. One of the reasons for this is the screening that is done on patients before they undergo bariatric surgery, given that the presence of moderate or severe psychosis or dementia is one of the exclusion criteria. ${ }^{55}$ Unlike most other studies, ours showed that the use of antidepressants decreased among the patients after the surgical procedure. Use of some classes of antidepressants, especially selective serotonin reuptake inhibitors, has been indicated as an adjunct in treatments for obesity. ${ }^{43}$ This factor may be related to the decrease observed in our study.

Lopes $^{70}$ and Segal et al. ${ }^{71}$ also observed a tendency towards improvement in their patients' psychological functioning. Nevertheless, it is known that some psychiatric disorders may emerge during this period.

Over the long term, some authors have observed that several psychiatric conditions have been causes of death during the postoperative period, usually through suicide. Depression has been reported to be one of the most frequent late complications $(23.4 \%) .^{72-75}$

van Hout et al. ${ }^{76}$ pointed out that the psychiatric effects of bariatric surgery might take from 6 to 24 months to emerge. It has been suggested that the levels of anxiety and depression probably will not be significantly different six months after surgery, ${ }^{77}$ and that improvements in depressive conditions might only be observed 12 months after the surgery. ${ }^{78}$

Regarding the daily dosage, decreases were observed in relation to both fluoxetine and citalopram. According to previous reports in the literature, these effects may occur through discontinuation of use of selective serotonin reuptake inhibitors (SSRIs). Therefore, abrupt discontinuation of these drugs should be avoided whenever possible. ${ }^{43}$ The small reductions in antidepressant use and daily dosages observed in our study may have been partially related to this, since complete withdrawal of these drugs may have serious effects.

\section{Anti-inflammatory drugs and painkillers}

The high frequency of use of anti-inflammatory drugs during the preoperative period may be explained by the fact that obesity contributes towards development of inflammatory diseases in the joints. Moreover, anti-inflammatory drugs are efficient possibly because obesity is a proinflammatory condition. ${ }^{79}$ 
Inflammatory diseases of the joints are more common in obese people probably precisely due to their overweight condition. Therefore, the need for these drugs decreases through surgery, ${ }^{80}$ given that patients have less need for them, for treating pain, fever and inflammation, after they have lost some excess weight.

The use of anti-inflammatory drugs decreased by $78.5 \%$, which corroborated previous findings. Furthermore, there was also a $35.3 \%$ reduction in the use of painkillers, and $33.3 \%$ regarding muscle relaxants. Among the painkillers, only for dipyrone was there an increase in consumption, which may have been due to the standard prescription issued by the surgical team during the postoperative period. It is possible that this medical prescription may have influenced the choice of analgesic in selfmedication situations. It is important to point out that these last two drug classes were the ones most often used in self-medication, thus suggesting that bariatric surgery decreased the need for their use among the patients.

Our results support and reinforce previous findings in the literature regarding the impact of bariatric surgery on the use of some drug classes. ${ }^{28,31}$

One limitation of our study was the small sample size. However, few studies have assessed dosage reductions among the drugs that continue to be used after bariatric surgery. ${ }^{81,82}$ Consequently, the data presented in this study provide further details of the benefits of this procedure for patients.

Within this context, there is a need for more comprehensive studies with larger sample sizes and longer follow-up, especially in Brazil, where studies correlating weight loss with drug use, with pharmacokinetic assessments before and after bariatric surgery, are still scarce. Moreover, these studies need to address other factors that may have influenced the increase or decrease in use of some drug classes, such as adherence to treatment, side effects, access to drugs and economic factors, among others.

With the rampant growth of obesity, implementation of prevention policies is also a relevant approach to be considered within public health management, so as not only to prevent obesity but also to prevent its complications due to associated comorbidities, drug use, side effects, reduced quality of life and even societal prejudice.

\section{CONCLUSION}

Based on the data obtained, bariatric surgery was observed to enable decreased need for some of the drug classes used, and also adjustment of the dosages of the drugs that continued to be prescribed. On the other hand, new drug classes were included in the patients' therapeutic plans, such as vitamins, drugs for gastrointestinal tract disorders and antianemic drugs, as a result of the limitations imposed by the procedure.

\section{REFERENCES}

1. Brasil. Ministério da Saúde. Vigitel Brasil 2013 - Vigilância de fatores de risco e proteção para doenças crônicas por inquérito telefônico. Brasília: Ministério da Saúde; 2014. Available from: http://www.prefeitura.sp.gov.br/cidade/secretarias/upload/ saude/arquivos/morbidade/Vigitel-2013.pdf. Accessed in 2016 (Jun 2).

2. World Health Organization. Obesity and overweight. Available from: http://www.who.int/mediacentre/factsheets/fs311/en/index.html. Accessed in 2016 (Jun 2).

3. Barja-Fernandez S, Leis R, Casanueva FF, Seoane LM. Drug development strategies for the treatment of obesity: how to ensure efficacy, safety, and sustainable weight loss. Drug Des Devel Ther. 2014;8:2391-400.

4. McTigue KM, Harris R, Hemphill B, et al. Screening and interventions for obesity in adults: summary of the evidence for the U.S. Preventive Services Task Force. Ann Intern Med. 2003;139(11):933-49.

5. Guh DP, Zhang W, Bansback N, et al. The incidence of co-morbidities related to obesity and overweight: a systematic review and metaanalysis. BMC Public Health. 2009;9:88.

6. Blüher M. Adipose tissue dysfunction in obesity. Exp Clin Endocrinol Diab. 2009;117:241-50.

7. Baretić M. Obesity drug therapy. Minerva Endocrinol. 2013; 38(3):245-54.

8. Kissler HJ, Settmacher U. Bariatric surgery to treat obesity. Semin Nephrol. 2013;33(1):75-89.

9. Gelber RP, Gaziano JM Manson JE, Buring JE, Sesso HD. A prospective study of body mass index and the risk of developing hypertension in men. Am J Hypertens. 2007;20(4):370-7.

10. Piché ME, Auclair A, Harvey J, Marceau S, Poirier P. How to choose and use bariatric surgery in 2015. Can J Cardiol. 2015;31 (2):153-66.

11. Geraldo M de S, Fonseca FL, Gouveia MR, Feder D. The use of drugs in patients who have undergone bariatric surgery. Int J Gen Med. 2014;7:219-24

12. Xu XJ, Apovian C, Hess D, et al. Improved Insulin Sensitivity 3 Months After RYGB Surgery is Associated With Increased Subcutaneous Adipose Tissue AMPK Activity and Decreased Oxidative Stress. Diabetes. 2015;64(9):3155-9.

13. Sjöström L. Review of the key results from the Swedish Obese Subjects (SOS) trial - a prospective controlled intervention study of bariatric surgery. J Intern Med. 2013;273(3):219-34.

14. Buchwald H, Avidor Y, Braunwald E, et al. Bariatric surgery: a systematic review and meta-analysis. JAMA. 2004;292(14):1724-37.

15. Gould JC, Garren MJ, Starling JR. Laparoscopic gastric bypass results in decreased prescription medication costs within 6 months. J Gastrointest Surg. 2004;8(8):983-7.

16. Nguyen NT, Varela JE, Sabio A, et al. Reduction in prescription medication costs after laparoscopic gastric bypass. Am Surg. 2006;72(10):853-6. 
17. Sjöström $L$, Lindroos $A K$, Peltonen $M$, et al. Lifestyle, diabetes, and cardiovascular risk factors 10 years after bariatric surgery. $\mathrm{N}$ Engl J Med. 2004;351(26):2683-93.

18. Benaiges D, Goday A, Ramon JM, et al. Laparoscopic sleeve gastrectomy and laparoscopic gastric bypass are equally effective for reduction of cardiovascular risk in severely obese patients at one year of follow-up. Surg Obes Relat Dis. 2011;7(5):575-80.

19. Kwok CS, Pradhan A, Khan MA, et al. Bariatric surgery and its impact on cardiovascular disease and mortality: a systematic review and meta-analysis. Int J Cardiol. 2014;173(1):20-8.

20. Sjöström $L$, Peltonen $M$, Jacobson P, et al. Bariatric surgery and longterm cardiovascular events. JAMA. 2012;307(1):56-65.

21. Malone M, Alger-Mayer S, Lindstrom J, Bailie GR. Management of iron deficiency and anemia after Roux-en-Y gastric bypass surgery: an observational study. Surg Obes Relat Dis. 2013;9(6):969-74.

22. Brasil. Ministério da Saúde. Gabinete do Ministro. Portaria n 424, de 19 de março de 2013. Redefine as diretrizes para a organização da prevenção e do tratamento do sobrepeso e obesidade como linha de cuidado prioritária da Rede de Atenção à Saúde das Pessoas com Doenças Crônicas. Brasília, 2013. Available from: http://bvsms.saude.gov.br/bvs/saudelegis/ gm/2013/prt0424_19_03_2013.html. Accessed in 2016 (Jun 2).

23. National Institute of Health. Bariatric surgery for severe obesity. Weight-control Information Network; 2011. Available from: http:// win.niddk.nih.gov/publications/PDFs/Bariatric_Surgery_508.pdf. Accessed in 2016 (Jun 2).

24. Conselho Federal de Medicina. Resolução CFM № 1.942/2010. Normas seguras para o tratamento cirúrgico da obesidade mórbida, definindo indicações, procedimentos e equipe. Publicada no D. O. U. de 12 de fevereiro de 2010, Seção I, p. 72. Available from: http:// www.portalmedico.org.br/resolucoes/CFM/2010/1942_2010.htm. Accessed in 2016 (Jun 2).

25. Snow LL, Weinstein LS, Hannon JK, et al. The effect of Roux-en-Y gastric bypass on prescription drug costs. Obes Surg. 2004;14(8):1031-5.

26. Maciejewski ML, Livingston EH, Kahwati LC, et al. Discontinuation of diabetes and lipid-lowering medications after bariatric surgery at Veterans Affairs medical centers. Surg Obes Rel Dis. 2010;6(6):601-7.

27. Potteiger CE, Paragi PR, Inverso NA, et al. Bariatric surgery: shedding the monetary weight of prescription costs in the managed care arena. Obes Surg. 2004;14(6):725-30.

28. Narbro K, Agren G, Jonsson E, et al. Pharmaceutical costs in obese individuals: comparison with a randomly selected population sample and long-term changes after conventional and surgical treatment: the SOS intervention study. Arch Intern Med. 2002;162(18):2061-9.

29. Lopes EC, Heineck I, Athaydes G, et al. Is Bariatric Surgery Effective in Reducing Comorbidities and Drug Costs? A Systematic Review and Meta-Analysis. Obes Surg. 2015;25(9):1741-9.

30. Yu J, Zhou X, Li L, et al. The long-term effects of bariatric surgery for type 2 diabetes: systematic review and meta-analysis of randomized and non-randomized evidence. Obes Surg. 2014;25(1):143-58.
31. Buchwald H, Estok R, Fahrbach K, et al. Weight and type 2 diabetes after bariatric surgery: systematic review and meta-analysis. Am J Med. 2009;122(3):248-256.e5.

32. Garrido-Sanchez L, Murri M, Rivas-Becerra J, et al. Bypass of the duodenum improves insulin resistance much more rapidly than sleeve gastrectomy. Surg Obes Relat Dis. 2012;8(2):145-50.

33. Pories WJ, Mehaffey JH, Staton KM. The surgical treatment of type two diabetes mellitus. Surg Clin North Am. 2011;91(4):821-36, viii.

34. Schauer PR, Kashyap SR, Wolski K, et al. Bariatric surgery versus intensive medical therapy in obese patients with diabetes. $N$ Engl J Med. 2012;366(17):1567-76.

35. Laferrère $B$, Heshka $S$, Wang $K$, et al. Incretin levels and effect are markedly enhanced 1 month after Roux-en-Y gastric bypass surgery in obese patients with type 2 diabetes. Diabetes Care. 2007;30(7):1709-16.

36. Aron-Wisnewsky J, Clement K. The effects of gastrointestinal surgery on gut microbiota: potential contribution to improved insulin sensitivity. Curr Atheroscler Rep. 2014;16(11):454.

37. Simonen M, Dali-Youcef N, Kaminska D, et al. Conjugated bile acids associate with altered rates of glucose and lipid oxidation after Rouxen-Y gastric bypass. Obes Surg. 2012;22(9):1473-80.

38. Kohli R, Bradley D, Setchell KD, et al. Weight loss induced by Roux-en-Y gastric bypass but not laparoscopic adjustable gastric banding increases circulating bile acids. J Clin Endocrinol Metab. 2013;98(4):E708-12.

39. Bhutta HY, Raipal N, White W, et al. Effect of Roux-en-Y gastric bypass surgery on bile acid metabolism in normal and obese diabetic rats. PLos One. 2015;10(3):e0122273.

40. Kashyap SR, Gatmaitan P, Brethauer S, Schauer P. Bariatric surgery for type 2 diabetes: weighing the impact for obese patients. Cleve Clin J Med. 2010;77(7):468-76.

41. Rhee NA, Vilsbøll T, Knop FK. Current evidence for a role of GLP-1 in Roux-en-Y gastric bypass-induced remission of type 2 diabetes. Diabetes Obes Metab. 2012;14(4):291-8,

42. Neff KJ, O'Shea D, le Roux CW. Glucagon like peptide-1 (GLP-1) dynamics following bariatric surgery: a Signpost to a new frontier. Curr Diabetes Rev. 2013;9(2):93-101.

43. American Society of Health-System Pharmacists. AHFS: Drug information. Bethesda: ASHP; 2014

44. Aron-Wisnewsky J, Lemaitre F, Clément K, et al. Pharmacokinetics of immunomodulator treatments after roux-en-y bypass in obese patient. J Clin Pharmacol. 2013;53(7):779-84

45. Oria HE, Moorehead MK. Bariatric analysis and reporting outcome system (BAROS). Obes Surg. 1998:8(5):487-99.

46. González P JF, Gómez C G, Arriagada P G. Evaluación mediante score Baros de los resultados del bypass gástrico en el tratamiento de la obesidad mórbida [Evaluation of gastric bypass surgery using the Baros score]. Rev Chil Cir. 2006;58(5):365-70.

47. Vest AR, Heneghan HM, Agarwal S, Schauer PR, Young JB. Bariatric surgery and cardiovascular outcomes: a systematic review. Heart. 2012;98(24):1763-77. 
48. Ricci NA, Pessoa GS, Ferriolli E, Dias RC, Perracini MR. Frailty and cardiovascular risk in community-dwelling elderly: a populationbased study. Clin Interv Aging. 2014;9:1677-85.

49. Hinojosa MW, Varela JE, Smith BR, Che F, Nguyen NT. Resolution of systemic hypertension after laparoscopic gastric bypass. J Gastrointest Surg. 2009;13(4):793-7.

50. Pajecki D, Dalcanalle L, Souza de Oliveira CP, et al. Follow-up of Rouxen-Y gastric bypass patients at 5 or more years postoperatively. Obes Surg. 2007;17(5):601-7.

51. Masuo K, Mikami H, Ogihara T, Tuck ML. Differences in mechanisms between weight loss-sensitive and -resistant blood pressure reduction in obese subjects. Hypertens Res. 2001;24(4):371-6.

52. Reisin E, Frohlich ED, Messerli FH, et al. Cardiovascular changes after weight reduction in obesity hypertension. Ann Intern Med. 1983;98(3):315-9.

53. Tuck ML, Sowers J, Dornfeld L, Kledzik G, Maxwell M. The effect of weight reduction on blood pressure, plasma rennin activity, and plasma aldosterone levels in obese patients. N Engl J Med. 1981;304(16):930-3.

54. Dixon JB, O'Brien PE. Lipid profile in the severely obese: changes with weight loss after lap-band surgery. Obes Res. 2002;10(9):903-10.

55. Crémieux P, Ledoux S, Clerici C, Cremieux F, Buessing M. The impact of bariatric surgery on comorbidities and medication use among patients. Obes Surg. 2010;20(7):861-70.

56. Pournaras DJ, le Roux CW. After bariatric surgery, what vitamins should be measured and what supplements should be given? Clin Endocrinol (Oxf). 2009;71(3):322-5.

57. Miller AD, Smith KM. Medication and nutrient administration considerations after bariatric surgery. Am J Health Syst Pharm. 2006;63(19):1852-7.

58. Ravelli MN, Merhi VAL, Mônaco DV, Aranha N. Obesidade, cirurgia bariátrica e implicações nutricionais. Revista Brasileira em Promoção da Saúde. 2007;20(4):259-66. Available from: http://ojs.unifor.br/ index.php/RBPS/article/view/1036/2196. Accessed in 2016 (Jun 2).

59. Gehrer S, Kern B, Peters T, Christofiel-Courtin C, Peterli R. Fewer nutrient deficiencies after laparoscopic sleeve gastrectomy (LSG) than after laparoscopic Roux-Y-gastric bypass (LRYGB)-a prospective study. Obes Surg. 2010;20(4):447-53.

60. Stein J, Stier C, Raab H, Weiner R. Review article: The nutritional and pharmacological consequences of obesity surgery. Aliment Pharmacol Ther. 2014;40(6):582-609.

61. Reinehr $\mathrm{T}$, Roth $\mathrm{CL}$. The gut sensor as regulator of body weight. Endocrine. 2015;49(1):35-50.

62. Fontana MA, Wohlgemuth SD. The surgical treatment of metabolic disease and morbid obesity. Gastroenterol Clin North Am. 2010;39(1):125-33.

63. Rasmussen JJ, Fuller W, Ali MR. Marginal ulceration after laparoscopic gastric bypass: an analysis of predisposing factors in 260 patients. Surg Endosc. 2007;21(7):1090-4.
64. Sidani S, Akkary E, Bell R. Catastrophic bleeding from a marginal ulcer after gastric bypass. JSLS. 2013;17(1):148-51.

65. Sapala JA, Wood MH, Sapala MA, Flake TM Jr. Marginal ulcer after gastric bypass: a prospective 3-year study of 173 patients. Obes Surg. 1998;8(5):505-16.

66. D'Hondt MA, Pottel H, Devriendt D, Van Rooy F, Vansteenkiste F. Can a short course of prophylactic low-dose proton pump inhibitor therapy prevent stomal ulceration after laparoscopic Roux-en-Y gastric bypass? Obes Surg. 2010;20(5):595-9.

67. Sanyal AJ, Sugerman HJ, Kellum JM, Engle KM, Wolfe L. Stomal complications of gastric bypass: incidence and outcome of therapy. Am J Gastroenterol. 1992;87(9):1165-9.

68. Jordan WH, Hocking MP, Rout WR, Woodward ER. Marginal ulcer following gastric bypass for morbid obesity. Am Surg. 1991;57(5):286-8.

69. Pope GD, Goodney PP, Burchard KW, et al. Peptic ulcer/stricture after gastric bypass: a comparison of technique and acid suppression variables. Obes Surg. 2002;12(1):30-3.

70. Lopes EC. Impacto da cirurgia bariátrica na qualidade de vida e nos gastos com medicamentos em uma população de usuários do SUS [thesis]. Porto Alegre: Universidade Federal do Rio Grande do Sul; 2013.

71. Segal JB, Clark JM, Shore AD, et al. Prompt reduction in use of medications for comorbid conditions after bariatric surgery. Obes Surg. 2009;19(12):1646-56

72. Fandiño J, Benchimol AK, Coutinho WF, Appolinário JC. Cirurgia bariátrica: aspectos clínico-cirúrgicos e psiquiátricos [Bariatric surgery: clinical, surgical and psychiatric aspects]. Rev Psiquiatr Rio Gd Sul. 2004;26(1):47-51.

73. Kodama K, Noda S, Murakami A, et al. Depressive disorders as psychiatric complications after obesity surgery. Psychiatry Clin Neurosci. 1998;52(5):471-6.

74. Pories WJ, Swanson MS, MacDonald KG, et al. Who would have thought it? An operation proves to be the most effective therapy for adult-onset diabetes mellitus. Ann Surg. 1995;222(3):339-50; discussion 350-2.

75. Capella JF, Capella RF. The weight reduction operation of choice: vertical banded gastroplasty or gastric bypass. Am J Surg. 1996;171(1):74-9.

76. van Hout G, van Heck G. Bariatric psychology, psychological aspects of weight loss surgery. Obes Facts. 2009;2(1):10-5.

77. Matini D, Ghanbari Jolfaei A, Pazouki A, Pishgahroudsari M, Ehtesham $M$. The comparison of severity and prevalence of major depressive disorder, general anxiety disorder and eating disorders before and after bariatric surgery. Med J Islam Repub Iran. 2014;28:109.

78. Peterhänsel C, Wagner B, Dietrich A, Kersting A. Obesity and comorbid psychiatric disorders as contraindications for bariatric surgery? A case study. Int J Surg Case Rep. 2014;5(12):1268-70.

79. Frank P, Crookes PF. Short- and long-term surgical follow-up of the postbariatric surgery patient. Gastroenterol Clin North Am. 2010;39(1):135-46 
80. Dhabuwala A, Cannan RJ, Stubbs RS. Improvement in co-morbidities following weight loss from gastric bypass surgery. Obes Surg. 2000;10(5):428-35

81. Hodo DM, Waller JL, Martindale RG, Fick DM. Medication use after bariatric surgery in a managed care cohort. Surg Obes Relat Dis. 2008;4(5):601-7.

82. Schlienger JL, Pradignac A, Luca F, Meyer L, Rohr S. Medical management of diabetes after bariatric surgery. Diabetes Metab. 2009;35(6 Pt 2):558-61.

Sources of funding: Coordenação de Aperfeiçoamento de Pessoal de Nível Superior/CNPq (Procedural no. 479383/2008-1)

\section{Conflict of interest: None}

Date of first submission: November 23, 2015

Last received: April 24, 2016

Accepted: May 3, 2016

\section{Address for correspondence:}

Charline Fernanda Backes

Faculdade de Farmácia, Universidade Federal do Rio Grande do Sul (UFRGS)

Av. Ipiranga, 2.752 — sala 203

Azenha - Porto Alegre (RS) — Brasil

CEP 90610-000

Tel. (+55 51) 3308-5281

E-mail: charlinefernandabb@gmail.com 